\title{
UCP2 and UCP3 in muscle controlling body metabolism
}

Citation for published version (APA):

Schrauwen, P., \& Hesselink, M. K. C. (2002). UCP2 and UCP3 in muscle controlling body metabolism. Journal of Experimental Biology, 205(Pt 15), 2275-2285. http://www.ncbi.nlm.nih.gov/entrez/query.fcgi?cmd=Retrieve\&db=PubMed\&list_uids=12110661\&dopt=Abs tract

Document status and date:

Published: 01/01/2002

Document Version:

Publisher's PDF, also known as Version of record

Document license:

Taverne

Please check the document version of this publication:

- A submitted manuscript is the version of the article upon submission and before peer-review. There can be important differences between the submitted version and the official published version of record.

People interested in the research are advised to contact the author for the final version of the publication, or visit the DOI to the publisher's website.

- The final author version and the galley proof are versions of the publication after peer review.

- The final published version features the final layout of the paper including the volume, issue and page numbers.

Link to publication

\footnotetext{
General rights rights.

- You may freely distribute the URL identifying the publication in the public portal. please follow below link for the End User Agreement:

www.umlib.nl/taverne-license

Take down policy

If you believe that this document breaches copyright please contact us at:

repository@maastrichtuniversity.nl

providing details and we will investigate your claim.
}

Copyright and moral rights for the publications made accessible in the public portal are retained by the authors and/or other copyright owners and it is a condition of accessing publications that users recognise and abide by the legal requirements associated with these

- Users may download and print one copy of any publication from the public portal for the purpose of private study or research.

- You may not further distribute the material or use it for any profit-making activity or commercial gain

If the publication is distributed under the terms of Article $25 \mathrm{fa}$ of the Dutch Copyright Act, indicated by the "Taverne" license above, 


\title{
Review
}

\section{UCP2 and UCP3 in muscle controlling body metabolism}

\author{
Patrick Schrauwen ${ }^{1, *}$ and Matthijs Hesselink ${ }^{2}$ \\ Nutrition and Toxicology Research Institute Maastricht (NUTRIM), ${ }^{1}$ Department of Human Biology and \\ ${ }^{2}$ Department of Movement Sciences, Maastricht University, The Netherlands \\ *Present address: Department of Human Biology, Maastricht University, PO Box 616, 6200 MD Maastricht, The Netherlands \\ (e-mail: p.schrauwen@hb.unimaas.nl)
}

Accepted 13 May 2002

\begin{abstract}
Summary
The uncoupling protein-1 (UCP1) homologues UCP2 and UCP3 are able to uncouple ATP production from mitochondrial respiration, thereby dissipating energy as heat and affecting energy metabolism efficiency. In contrast to UCP1, which plays an important role in adaptive thermogenesis, UCP2 and UCP3 do not have a primary role in the regulation of energy metabolism. UCP2, which is expressed in a wide variety of tissues, including white adipose tissue, skeletal muscle and tissues of the immune system, has been suggested to affect the production of reactive oxygen species. UCP2 has also been suggested to regulate the $[\mathrm{ATP}] /[\mathrm{ADP}]$ ratio and was recently shown to influence insulin secretion in the $\beta$-cells of the pancreas. UCP3, in contrast, is expressed

energy expenditure, upregulates UCP3 expression. Moreover, UCP3-knockout mice have a normal metabolic rate. The exact function of UCP3 therefore remains to be elucidated, but putative roles for UCP3 include involvement in the regulation of ROS, in mitochondrial fatty acid transport and in the regulation of glucose metabolism in skeletal muscle. Whatever the primary function of these novel uncoupling proteins, a secondary effect via uncoupling might allow them to influence (but not to regulate) energy metabolism, which would be consistent with the observations from linkage and association studies. Therefore, UCP2 and UCP3 remain interesting targets for pharmacological upregulation in the treatment of obesity and diabetes.
\end{abstract} predominantly in skeletal muscle and has been associated with whole-body energy metabolism. However, the primary function of UCP3 is not the regulation of energy metabolism. For example, fasting, a condition attenuating

Key words: uncoupling protein, energy expenditure, obesity, diabetes, fatty acid metabolism.

\section{Introduction}

In living cells, adenosine triphosphate (ATP) can release the energy that is necessary for life by donating one or two phosphate groups, leaving adenosine diphosphate (ADP) or adenosine monophosphate (AMP), respectively. However, energy storage in the form of ATP is limited and, therefore, ATP has to be resynthesised continuously in the mitochondria. To resynthesize ATP from ADP, substrates such as fat, carbohydrate and proteins are metabolised, resulting in the production of NADH and $\mathrm{FADH}_{2}$. Subsequently, NADH and $\mathrm{FADH}_{2}$ can be oxidised to $\mathrm{NAD}^{+}, \mathrm{FAD}$ and $\mathrm{H}^{+}$in the respiratory chain.

According to the Nobel-prize-winning chemiosmotic hypothesis of Mitchell (Mitchell, 1966), the protons are transported to the cytosolic side of the inner mitochondrial membrane by a series of reactions. This eventually generates a proton gradient across the membrane, which causes protons to flow back across the inner mitochondrial membrane through a so-called $\mathrm{F}_{0} \mathrm{~F}_{1}$-complex. The energy thus generated is used by ATPase to transform ADP into ATP. In this way, substrate oxidation is coupled to the formation of ATP. In living cells, and in animals/humans under resting conditions, ATP is continuously consumed by, among other processes, the $\mathrm{Na}^{+} / \mathrm{K}^{+}$ pump $\left(\mathrm{Na}^{+} / \mathrm{K}^{+}\right.$-ATPase $)$, which is responsible for approximately $20 \%$ of ATP consumption, protein turnover (12-25\%) and the $\mathrm{Ca}^{2+}$ pump ( $\mathrm{Ca}^{2+}$-ATPase) (4-6\%). Furthermore, in active animals/humans, muscle contraction is a significant contributor to ATP consumption.

The coupling between substrate oxidation and ATP formation is not $100 \%$ efficient. The proton gradient, which is built up by the oxidation of substrates, can be reduced by socalled proton leaks, thereby diminishing the efficiency of ATP synthesis from substrate oxidation and thus dissipating energy as heat. The mechanism by which proton leaks reduce the proton gradient is not completely understood, but it has been proposed that uncoupling proteins (UCPs) are involved. These proteins could either transport protons into the mitochondrial 


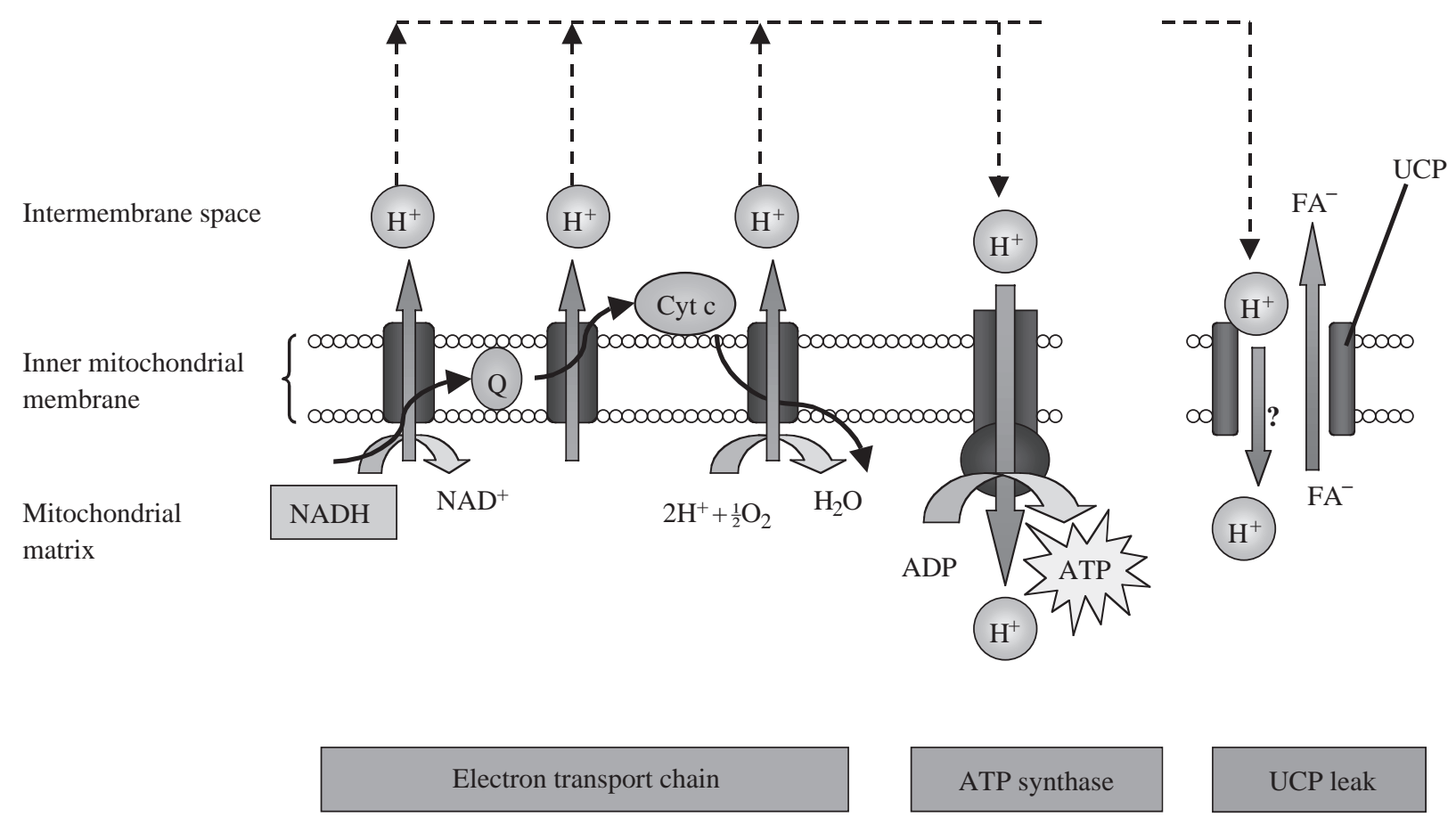

Fig. 1. Action of the electron transport chain leading to the build-up of a proton gradient across the inner mitochondrial membrane. Protons can cross the inner mitochondrial membrane via the $\mathrm{F}_{0} \mathrm{~F}_{1}$ complex, thereby providing energy for the conversion of ADP to ATP. Alternatively, the proton gradient can be reduced by uncoupling proteins (UCP), either by direct transport of protons from the intermembrane space to the matrix or by transport of fatty acid anions in the opposite direction. Cyt c, cytochrome $c$. Q, coenzyme Q.

matrix (Klingenberg et al., 1999) or transport non-esterified fatty acid anions out of the matrix in a process called fatty acid cycling (Jezek et al., 1998). Both these processes would reduce the proton gradient across the inner mitochondrial membrane (Fig. 1).

Although the rationale for proton leaks is not understood, they are a feature common to all living cells.

\section{Adaptive thermogenesis}

Adaptive thermogenesis, the dissipation of energy in the form of heat in response to external stimuli, has been implicated in the regulation of energy balance and body temperature. In rodents, adaptive thermogenesis in response to cold-exposure and high-fat feeding is accomplished by the activation of the brown adipose tissue. Brown adipose tissue can increase its thermogenic activity by decreasing the efficiency of coupling between respiration and ATP production (i.e. by increasing the magnitude of the 'proton leak'), leading to the generation of heat. In this way, brown adipose tissue helps rodents to survive periods of cold (by producing extra heat). In contrast, by decreasing the activity of brown adipose tissue (reducing the proton leak), energy can be saved during periods of starvation, as is the case during hibernation.

This feature of brown adipose tissue has led to the search for and identification of a protein responsible for this proton leak. In 1978, it was demonstrated that a $32 \mathrm{kDa}$ mitochondrial membrane protein, then called uncoupling protein or thermogenin and later renamed UCP1, was responsible for the thermogenic activity of brown adipose tissue (Nicholls et al., 1978). Exposure of mammals to cold results in an acute increase in metabolic rate through shivering thermogenesis, i.e. muscular activity producing heat. However, if cold exposure is prolonged, shivering ceases, but metabolic rate remains elevated. This non-shivering thermogenesis is mainly accounted for by an increase in the activity of the brown adipose tissue and is accompanied by a marked increase in the expression of UCP1 (Desautels et al., 1978).

Upon overfeeding, the expression of UCP1 in the brown adipose tissue of rodents is also upregulated, and this correlates closely with decreased metabolic efficiency and the prevention of the development of obesity (Himms-Hagen, 1984). In contrast, fasting is associated with an increase in metabolic efficiency and a decrease in UCP1 expression and activity (Rothwell et al., 1984). These findings illustrate the importance of UCP1 in the regulation of body temperature and energy balance in rodents.

More definitive evidence for a unique role of UCP1 in adaptive thermogenesis came with the creation of mice lacking UCP1. These mice are indeed unable to maintain their body temperature when exposed to cold (Enerback et al., 1997). Gradual acclimatisation to a colder environment extends the life span of these mice, but only by maintaining shivering thermogenesis. When shivering thermogenesis can no longer be maintained, these mice are no longer able to survive in the cold. This finding clearly illustrates that no other protein or 
Table 1. Linkage and association studies of the human UCP2 gene

\begin{tabular}{|c|c|c|c|c|}
\hline Trait & Population & Marker & Effect & Reference \\
\hline \multirow[t]{5}{*}{ Energy metabolism } & Caucasians & Ala/Val55 & $\begin{array}{l}\text { Decreased } 24 \mathrm{~h} \mathrm{EE}, \\
\text { increased } 24 \mathrm{~h} \mathrm{RQ}\end{array}$ & Astrup et al. (1999) \\
\hline & Pima Indians & Ala/Val55, Ins/Del & $\begin{array}{l}\text { Increased metabolic rate } \\
\text { and } 24 \mathrm{~h} \mathrm{EE}\end{array}$ & Walder et al. (1998) \\
\hline & Quebec family study & Marker at $11 \mathrm{q} 13$ & $\begin{array}{l}\text { Linkage with metabolic } \\
\text { rate }\end{array}$ & Bouchard et al. (1997) \\
\hline & Caucasians & Ala/Val55 & $\begin{array}{l}\text { Increased exercise } \\
\text { energy efficiency }\end{array}$ & Buemann et al. (2001) \\
\hline & Metabolic syndrome & Ala/Val55 & Negative & Klannemark et al. (1998) \\
\hline Obesity & $\begin{array}{l}\text { Caucasians } \\
\text { South Indian women } \\
\text { German Caucasians } \\
\text { Danish Caucasians } \\
\text { Mexican Americans } \\
\text { Familial NIDDM }\end{array}$ & $\begin{array}{l}\text { G/A promotor } \\
\text { Ins/Del exon } 8 \\
\text { Ins/Del exon } 8 \\
\text { Ins/Del exon } 8 \\
\text { Marker at } 11 \mathrm{q} 13 \\
\text { Marker at } 11 \mathrm{q} 13\end{array}$ & $\begin{array}{l}\text { Reduced BMI } \\
\text { Increased BMI/leptin } \\
\text { Increased BMI } \\
\text { Negative } \\
\text { Negative } \\
\text { Negative }\end{array}$ & $\begin{array}{l}\text { Esterbauer et al. (2001) } \\
\text { Cassell et al. (1999) } \\
\text { Evans et al. (2001) } \\
\text { Dalgaard et al. (1999) } \\
\text { Comuzzie et al. (2000) } \\
\text { Elbein et al. (1997) }\end{array}$ \\
\hline Obesity/NIDDM & $\begin{array}{l}\text { Danish NIDDM/juvenile obesity } \\
\text { Japanese NIDDM/control } \\
\text { Japanese NIDDM/control } \\
\text { NIDDM morbidly obese/controls }\end{array}$ & $\begin{array}{l}\text { Ala/Val55 } \\
\text { Ala/Val55 } \\
\text { Ala/Val55, Ins/Del } \\
\text { Ala/Val55, Ins/Del }\end{array}$ & $\begin{array}{l}\text { Negative } \\
\text { Negative } \\
\text { Negative } \\
\text { Negative }\end{array}$ & $\begin{array}{l}\text { Urhammer et al. (1997) } \\
\text { Kubota et al. (1998) } \\
\text { Shiinoki et al. (1999) } \\
\text { Otabe et al. (1998) }\end{array}$ \\
\hline Childhood obesity & $\begin{array}{l}\text { Children 6-10 years old } \\
\text { Children } 7-13 \text { years old }\end{array}$ & $\begin{array}{l}\text { Ins/Del exon } 8 \\
\text { Ala/Val55 }\end{array}$ & $\begin{array}{l}\text { Increased BMI } \\
\text { Negative }\end{array}$ & $\begin{array}{l}\text { Yanovski et al. (2000) } \\
\text { Lentes et al. (1999) }\end{array}$ \\
\hline
\end{tabular}

NIDDM, non-insulin-dependent diabetes mellitus; Ins/Del, insertion/deletion; BMI, body mass index; EE, energy expenditure; RQ, respiratory quotient.

hormone could substitute for the absence of UCP1 in adaptive non-shivering thermogenesis (Golozoubova et al., 2001). Similarly, it has been shown that brown fat cells lacking UCP1 do not show the usual increase in the rate of oxygen consumption after administration of noradrenaline (Nedergaard et al., 2001). Together, these findings indicate that UCP1 plays a major role in adaptive non-shivering thermogenesis, at least in rodents.

In humans, the site of adaptive thermogenesis might not be restricted to brown adipose tissue. Adult humans have no large deposits of brown adipose tissue, although brown adipose fat cells may be present in small numbers within the white adipose tissue (Lean et al., 1986). As a result of the low content of brown adipose tissue from adult humans, its contribution to adrenaline-induced thermogenesis was estimated to be maximally $25 \%$, so other tissues must therefore be involved (Astrup et al., 1985). The same study showed that, in humans, skeletal muscle is the most important tissue for adaptive thermogenesis, accounting for up to $50 \%$ of adrenalineinduced thermogenesis. Comparable results were found by Simonsen et al. (1993), who estimated that $40 \%$ of the increase in thermogenesis after adrenaline administration could be attributed to skeletal muscle. Since UCP1, which is responsible for the thermogenic activity of brown adipose tissue, is not present in skeletal muscle, searches have been made for other (uncoupling) proteins that could contribute to adaptive thermogenesis in skeletal muscle.

\section{UCP2 as a regulator of energy metabolism}

In 1997, the first (human) homologue of UCP1 was discovered, called UCP2 (Fleury et al., 1997). In contrast to $\mathrm{UCP} 1$, which is expressed only in brown adipose tissue and is thus scarce in adults, UCP2 is expressed in a large number of tissues including skeletal muscle, white adipose tissue, spleen, lung and macrophages. Like UCP1, UCP2 has been shown to possess uncoupling activity when expressed in yeast (Fleury et al., 1997; Gimeno et al., 1997). An interesting finding, when mice lacking UCP1 were created, was that these mice are not obese. However, UCP1-knockout mice show a fivefold upregulation of UCP2, and it has therefore been suggested that UCP2 is involved in the regulation of energy metabolism and obesity. Indeed, Bouchard et al. (1997) showed that markers in the vicinity of $11 \mathrm{q} 13$, near the location of UCP2, are very strongly linked to resting energy expenditure. Genetic analysis showed several common polymorphisms in the UCP2 gene, amongst which are an alanine $\rightarrow$ valine substitution at amino acid 55, and a 45-base-pair insertion/deletion in the non-coding region of exon 8.

Using these polymorphisms, positive associations between the UCP2 gene and energy expenditure have been found (Astrup et al., 1999; Buemann et al., 2001; Walder et al., 1998), although one study found no such assocation (Klannemark et al., 1998). Studies focusing on the association between UCP2 polymorphisms and obesity (defined by body mass index or body composition) showed more diverse results, with some 
studies reporting a positive association (Cassell et al., 1999; Esterbauer et al., 2001; Evans et al., 2001; Yanovski et al., 2000) and others no association (Comuzzie et al., 2000; Dalgaard et al., 1999; Elbein et al., 1997; Kubota et al., 1998; Lentes et al., 1999; Otabe et al., 1998; Shiinoki et al., 1999; Urhammer et al., 1997) between UCP2 and obesity (Table 1).

Overall, these studies do reveal an association between UCP2 and energy metabolism, but this association is apparently not always reflected in obesity. It could be argued that the latter is surprising, considering that the development of obesity results from a misbalance between energy expenditure and energy intake. It is therefore unlikely that the phenotype obesity can be fully explained by (polymorphism in) a single gene. For example, an effect of UCP2 on metabolic rate could be compensated for by increased spontaneous physical activity and/or reduced food intake, even though a reduced metabolic rate predisposes to obesity (Ravussin et al., 1988; Trayhurn and Jennings, 1988; Tremblay et al., 1989). Therefore, the lack of association between UCP2 and obesity, as observed in the majority of studies, should not be interpreted as evidence against an important role for UCP2 in the regulation of (human) energy metabolism.

A more direct way to examine the relationship between UCP2 and (human) energy metabolism is to study UCP2 mRNA and protein expression experimentally together with simultaneous measurements of energy expenditure. Using this approach, it was shown that UCP2 mRNA levels in adipose tissue were positively related to resting metabolic rate (which accounts for $60-70 \%$ of total $24 \mathrm{~h}$ energy expenditure) (Barbe et al., 1998). Furthermore, administration of thyroid hormone to humans, resulting in a pronounced increase in energy expenditure, was shown to upregulate UCP2 mRNA expression in skeletal muscle (Barbe et al., 2001). These findings suggest that $\mathrm{UCP} 2$ is related to energy expenditure and could, therefore, be involved in the development of obesity. Indeed, it was shown in rodents that UCP2 mRNA expression is higher in obesity-resistant $(\mathrm{A} / \mathrm{J})$ mice than in obesity-prone (B6) mice. Furthermore, UCP2 mRNA expression was upregulated after feeding a high-fat diet in the A/J strain but not in the B6 strain mice, suggesting that the lack of upregulation of UCP2 in the latter could contribute to the high susceptibility to obesity of these mice (Fleury et al., 1997).

In humans, reduced UCP2 mRNA expression has been reported in the white adipose tissue (Oberkofler et al., 1998) and skeletal muscle (Nordfors et al., 1998) of obese subjects. Recently, a common polymorphism in the promotor of the human UCP2 gene has been described that influences UCP2 transcription when expressed in a cell system and is associated with increased UCP2 mRNA expression in human adipose tissue. Interestingly, this polymorphism was associated with a slightly reduced risk of obesity and, since the polymorphism is very common, it was concluded that it might account for up to $15 \%$ of obesity in humans (Esterbauer et al., 2001). Although this value might be too optimistic, the study does indicate that functional mutations in the UCP2 gene that affect $\mathrm{UCP} 2$ expression can influence the regulation of body mass in humans. Taken together, these studies indicate that UCP2 is, in one way or another, related to energy metabolism and obesity in rodents and humans.

\section{Alternative functions of UCP2: prevention of the formation of reactive oxygen species and as a regulator of [ATP]:[ADP] ratio}

Although several lines of evidence have been presented for a relationship between UCP2 and energy metabolism, doubt has arisen as to whether the primary function of UCP2 is the regulation of energy metabolism. First, the observation that UCP2 is upregulated during fasting, when energy expenditure falls (Millet et al., 1997), is not consistent with a role for UCP2 as a regulator of energy expenditure. Second, mice lacking UCP2 have been shown to have a normal metabolic rate and body mass (Arsenijevic et al., 2000). The lack of effect of UCP2 on energy metabolism and body mass in these mice has urged researchers to search for alternative functions for this novel uncoupling protein. The abundant expression of UCP2 mRNA in organs of the immune system prompted Arsenijevic et al. (2000) to investigate the immunological phenotype of UCP2-knockout mice. Surprisingly, UCP2-knockout mice appeared to be resistant to infection by Toxoplasma gondii, an intracellular parasite that lethally infects the brain of normal mice. To find causes for this unexpected resistance to infection, the researchers examined the macrophages of UCP2-knockout mice and found that these macrophages produced higher levels of reactive oxygen species (ROS), which are known to be associated with higher cytolytic activity. Earlier work of Skulachev (1998) had indicated that mild uncoupling could prevent a large increase in the mitochondrial proton gradient in situations in which no ADP is available for ATP synthesis and that this mild uncoupling could prevent the mitochondrial production of ROS, which is related to the size of the proton gradient. Thus, UCP2 could be involved in the regulation of radical production by reducing the proton gradient and therefore be beneficial for living cells, preventing them from damage to lipids, proteins and DNA by ROS.

A role for UCP2 as a regulator of ROS production had already been suggested by Nègre-Salvayre et al. (1997), who showed that the addition of GDP to brown adipocytes resulted in an increase in the electrical potential across the inner mitochondrial membrane and in ROS production. They assumed that this effect of GDP was due to inhibition of uncoupling activity by GDP. The same effect of GDP on ROS production was observed in liver mitochondria from nonparenchymal cells, but not in mitochondria from hepatocytes. Since the latter lack UCP2, they suggested that $\mathrm{UCP} 2$ might act to modulate ROS production and that UCP2 could, like UCP1, also be inhibited by the addition of GDP.

Apart from a role in regulating ROS production, UCP2 has also been implicated in the development of diabetes mellitus. Adenovirus-mediated overexpression of UCP2 in pancreatic islets has been shown to result in a decrease in glucosestimulated insulin secretion (Chan et al., 2001). Driven by this 
Table 2. Linkage and association studies of the human UCP3 gene

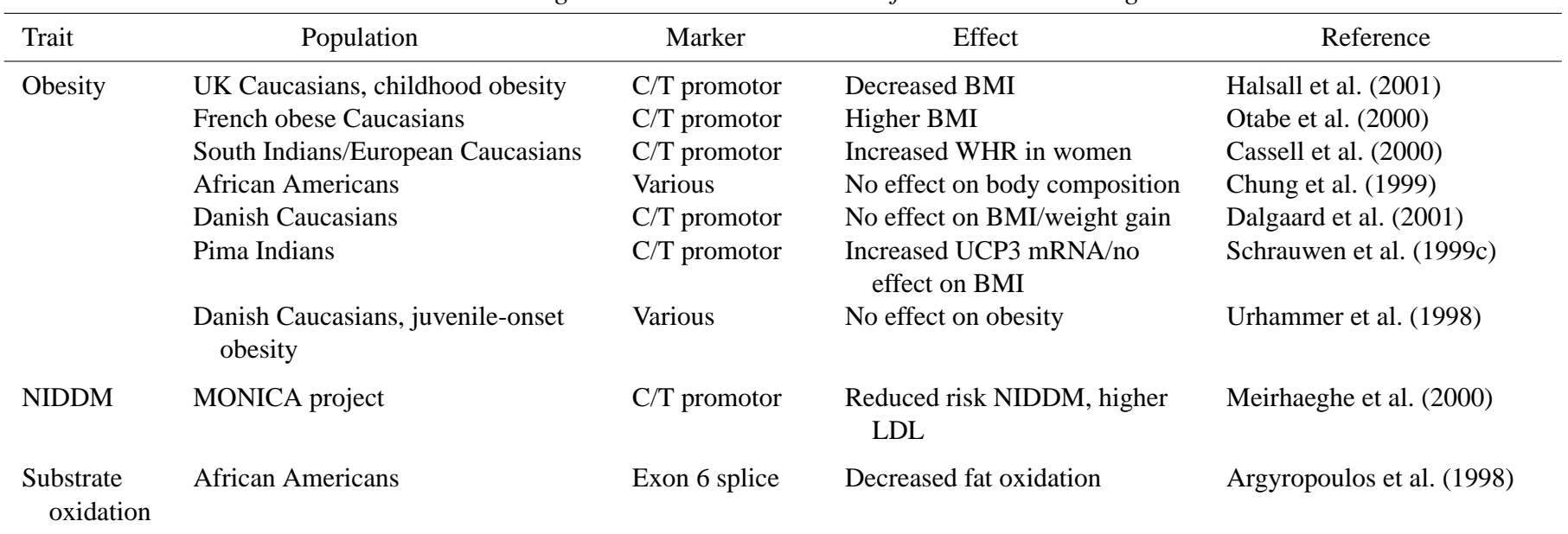

NIDDM, non-insulin-dependent diabetes mellitus; WHR, waist-to-hip ratio; LDL, low-density lipoprotein; MONICA project, MONItoring trends and determinants of CArdiovascular disease.

finding, Zhang et al. (2001) created mice lacking UCP2 and studied glucose metabolism and insulin secretion in these mice. In accordance with the results of Arsenijevic et al. (2000), they found no effect of the absence of UCP2 on body mass or coldinduced thermogenesis. However, UCP2-knockout mice had significantly lower glucose levels and elevated insulin concentrations, and the $\beta$-cells of UCP2-knockout mice showed increased insulin secretion. The mechanism behind these effects may originate from the influence of UCP2 on the $[\mathrm{ATP}] /[\mathrm{ADP}]$ ratio. In $\beta$-cells, an increase in $[\mathrm{ATP}]$ and/or [ATP]/[ADP] ratio (resulting from the metabolism of glucose) closes a membrane-bound ATP-sensitive $\mathrm{K}^{+}$channel, resulting in the influx of $\mathrm{Ca}^{2+}$ and subsequent insulin secretion.

Although these findings are interesting, they are difficult to interpret. At first sight, the findings suggest that a reduction in UCP2 expression in $\beta$-cells would be beneficial for the treatment of diabetes. However, the contrary seems to be the case for other tissues expressing UCP2. As discussed above, high levels of UCP2 expression in white adipose tissue and/or skeletal muscle are associated with a reduced risk of developing obesity, which is the most important risk factor for the development of type 2 diabetes mellitus. Furthermore, overexpression of UCP1 in skeletal muscle was recently shown to result in resistance to diet-induced diabetes ( $\mathrm{Li}$ et al., 2000). These data suggest that high levels of UCP expression would be beneficial in the prevention/treatment of diabetes mellitus. In addition, assuming a role for UCP2 in the regulation of ROS production, a low level of UCP2 expression would increase ROS production, which is particularly dangerous in the case of diabetes because recent data indicate that ROS production is the link between elevated glucose levels and hyperglycaemic damage (Nishikawa et al., 2000). In fact, overexpression of UCP1 in endothelial cells reduced ROS production and prevented hyperglycaemic damage (Nishikawa et al., 2000). Together, these results indicate that simply downregulating
UCP2 might not have the desired outcome regarding the prevention/treatment of diabetes mellitus.

Taken together, although studies using UCP2-knockout mice have given insight into the putative functions of this novel uncoupling protein, we are still a long way from completely understanding the function of UCP2. What seems to be clear, however, is that UCP2 indeed uncouples oxidative phosphorylation and thereby controls the $[\mathrm{ATP}] /[\mathrm{ADP}]$ ratio and inner mitochondrial membrane proton gradient. It is well known that the $[\mathrm{ATP}] /[\mathrm{ADP}]$ ratio plays an important role in the overall regulation of cellular function, making interpretation of studies with UCP2-knockout mice difficult. The fact that abolishing UCP2 expression results in interesting phenotypes indeed illustrates the importance of maintaining the $[\mathrm{ATP}] /[\mathrm{ADP}]$ ratio and inner mitochondrial membrane proton gradient within narrow ranges. However, it does not explain the physiological function of UCP2, because genetic manipulation of UCP2 cannot distinguish between the effect of manipulating [ATP]/[ADP] ratio and the effect of physiological induction of UCP2. Therefore, studies manipulating UCP2 expression within the physiological range, as well as studies examining the regulation of UCP2 in different tissues, are needed to obtain insight into the physiological function of UCP2.

\section{Is UCP3 the skeletal muscle analogue of the brown adipose tissue UCP1?}

After the discovery of UCP2 in 1997, a third uncoupling protein was discovered at the end of the same year (Boss et al., 1997). UCP3 is specifically expressed in skeletal muscle and brown adipose tissue. Like UCP1 and UCP2, UCP3 also reduces the proton gradient across the inner mitochondrial membrane when expressed in yeast (Boss et al., 1998b; Gong et al., 1997). The skeletal-muscle-specific expression of UCP3 
has made it an even better candidate gene than UCP2 to explain adaptive thermogenesis in muscle. Because UCP3 is located within $7 \mathrm{~kb}$ of the UCP2 gene (Solanes et al., 1997), the linkage and/or association between UCP2 and resting energy expenditure mentioned above (Bouchard et al., 1997) could also reflect a relationship between UCP3 and energy metabolism. We have detected a polymorphism in the promotor region of $\mathrm{UCP} 3$, a $\mathrm{C} \rightarrow \mathrm{T}$ substitution $55 \mathrm{bp}$ upstream of the transcription starting site, which was associated with increased UCP3 mRNA expression, but not with reduced BMI (Schrauwen et al., 1999c). The effects of this substitution as well as other UCP3 polymorphisms on markers of obesity have been studied with conflicting results (Cassell et al., 2000; Chung et al., 1999; Dalgaard et al., 2001; Halsall et al., 2001; Otabe et al., 2000; Urhammer et al., 1998) (Table 2).

To examine directly whether UCP3 mRNA is related to energy metabolism in humans, we used respiration chambers to measure human energy metabolism in detail and reverse transcriptase polymerase chain reaction (RT-PCR) to measure skeletal muscle UCP3 mRNA expression. We observed a positive correlation between sleeping metabolic rate and $24 \mathrm{~h}$ energy expenditure and the expression of UCP3 mRNA in Pima Indians (Schrauwen et al., 1999b). The lack of similar relationships in other studies (Bao et al., 1998) might be due to genetic difference between the populations studied. In this regard, it is important to note that sleeping metabolic rate in Pima Indians is a strong predictor of weight gain (Ravussin et al., 1988).

Further evidence for a relationship between UCP3 expression and energy metabolism comes from the finding that UCP3 mRNA expression is upregulated after thyroid hormone treatment, which is known to increase thermogenesis both in rodents (Gong et al., 1997) and in humans (Barbe et al., 2001). Furthermore, like UCP1 in brown adipose tissue, UCP3 is upregulated after the consumption of a high-fat diet in rodents (Gong et al., 1999) and humans (Schrauwen et al., 2001b). Finally, we and others have observed that UCP3 mRNA expression and UCP3 protein content are reduced after endurance training (Boss et al., 1998a; Schrauwen et al., 1999a) and after weight reduction (Schrauwen et al., 2000; Vidal-Puig et al., 1999), conditions both characterized by a reduced resting metabolic rate and/or increased metabolic efficiency.

\section{$\mathrm{UCP3}$ as a regulator of fuel metabolism}

Shortly after the discovery of UCP3, observations were made suggesting that UCP3 may not play a major role in energy metabolism. In rodents, cold exposure leads to a rapid increase in UCP1 expression in brown adipose tissue, allowing increased heat production to maintain body temperature. The skeletal muscle expression of UCP3 is also rapidly upregulated after cold exposure, with levels reaching a peak after 1 day, but prolonged cold exposure leads to a reduction in UCP3 mRNA expression (Lin et al., 1998). This suggests that UCP3 has no major role in adaptive thermogenesis because non- shivering thermogenesis starts to play a significant role after several days of cold exposure. We have recently shown that, in humans, $60 \mathrm{~h}$ of mild cold exposure reduced skeletal muscle UCP3 mRNA expression (Schrauwen et al., 2002b), excluding a major role for UCP3 in cold-induced adaptive thermogenesis. Another condition in which UCP3 expression does not reflect the changes in energy expenditure is fasting, during which energy expenditure drops and UCP3 mRNA expression increases both in rodents (Boss et al., 1998b) and in humans (Millet et al., 1997).

Experiments with UCP3-knockout mice further weakened the likelihood of an important role for UCP3 in the regulation of energy metabolism: these mice have no apparent phenotype, i.e. they are not obese and do not have an altered metabolic rate (Gong et al., 2000; Vidal-Puig et al., 2000). However, mice overexpressing UCP3 eat considerably more than their wild-type littermates, but do not become obese, suggesting that metabolic rate is increased in these animals (Clapham et al., 2000). Taken together, these results indicate that UCP3 is indeed able to uncouple oxidative phosphorylation in vivo, thereby dissipating energy as heat. However, as for UCP2, the effect of UCP3 on energy expenditure may be secondary to its primary physiological function. Again, the question arises as to what the function of this novel uncoupling protein could be.

\section{Does UCP3 play a role in type 2 diabetes mellitus?}

In accordance with the finding in UCP2-knockout mice, mitochondria isolated from mice lacking UCP3 also show increased ROS production (Vidal-Puig et al., 2000), and it has therefore been suggested that UCP3 may also be involved in reducing ROS production. However, the fact that the expression of UCP3 is restricted to skeletal muscle, whereas ROS are produced in the mitochondria of all tissues, makes UCP3 a less likely candidate for being involved in the prevention of the production of ROS.

In contrast, skeletal muscle is an important organ in maintaining glucose homeostasis, and diabetes mellitus is characterized by disturbances in skeletal muscle glucose metabolism. As mentioned above, overexpression of UCP1 in skeletal muscle results in resistance to diet-induced diabetes and improved skeletal muscle glucose transport (Li et al., 2000). In addition, mice overexpressing UCP3 have reduced plasma glucose and insulin levels (Clapham et al., 2000). Recently, Huppertz et al. (2001) showed that overexpression of UCP3 in L6 myotubes increases glucose uptake through an increased recruitment of the glucose transporter GLUT4 to the cell surface. In this context, it is interesting to note that exposure of rats to cold $\left(4^{\circ} \mathrm{C}\right)$, which is known to increase glucose utilization, leads to a concerted upregulation of UCP3 and GLUT4 mRNA expression after 6-24h and a concerted downregulation of the expression of both genes after 6 days (Lin et al., 1998). Also, after endurance exercise, UCP3 and GLUT4 mRNA expression increased in parallel (TsuboyamaKasaoka et al., 1998). These findings suggest that there is a close relationship between UCP3 expression and glucose 
metabolism in skeletal muscle. A characteristic of skeletal muscle is that it consists of different types of muscle fibres, with different capacities to oxidize glucose and fatty acids. Type 1 muscle fibres are equipped to oxidize fatty acids, whereas type $2 \mathrm{~b}$ muscle fibre are mainly able to oxidize glucose. In accordance with a relationship between UCP3 and glucose metabolism, we recently showed, using immunofluorescence, that UCP3 is expressed more abundantly in glycolytic type $2 \mathrm{~b}$ muscle fibres than in oxidative type 1 muscle fibres (Hesselink et al., 2001).

One proposed mechanism by which UCP3 could affect glucose uptake is via AMP kinase. The uncoupling of mitochondria results in a diminished ATP production and, hence, an increase in AMP concentration. The latter is known to activate AMP kinase, an enzyme responsible for the phosphorylation of key enzymes that control metabolic flux, including glucose uptake (via GLUT4 translocation) (Winder and Hardie, 1999). Taken together, these findings indicate a relationship between the presence of UCP3 and glucose metabolism and suggest that an impaired regulation of UCP3 could be involved in the aetiology of diabetes mellitus. However, direct comparisons of UCP3 mRNA levels in type 2 diabetic subjects with those in healthy controls revealed both decreased (Krook et al., 1998) and increased (Bao et al., 1998; Vidal et al., 1999) UCP3 mRNA expression. Although the reason for this discrepancy is not clear, it is possible that differences in diet, fasting period or exercise prior to the sampling of the biopsy could have contributed to the observed differences. Therefore, we recently determined UCP3 protein content, which is thought to be less variable than UCP3 mRNA expression, in type 2 diabetic subjects and healthy controls and found that UCP3 protein content in type 2 diabetic subjects was only $50 \%$ of that in healthy subjects (Schrauwen et al., 2001a). Whether this means that UCP3 is indeed involved in the aetiology of diabetes mellitus cannot be determined from these results. However, the $\mathrm{C} \rightarrow \mathrm{T}$ substitution in the UCP3 promotor mentioned above, associated with increased UCP3 mRNA expression, was recently found to be associated with a decreased risk of developing type 2 diabetes mellitus (Meirhaeghe et al., 2000).

If UCP3 is indeed involved in the aetiology of type 2 diabetes mellitus, it is a potential pharmacological target for the treatment of diabetes. For example, thiazolidinediones, a novel class of blood-glucose-lowering drugs that improve glycaemic control and insulin-sensitivity (Day, 1999), were shown to upregulate skeletal muscle UCP3 mRNA expression in rodents (Emilsson et al., 2000; Oberkofler et al., 2000). It is not known whether the upregulation of UCP3 expression by thiazolidinediones is responsible for the improved glucose tolerance or whether similar effects can be observed in humans. However, if this is the case, agents specifically able to upregulate UCP3 expression could be helpful in the treatment of diabetes mellitus.

\section{Is UCP3 a transporter of fatty acids?}

As mentioned above, UCP3 mRNA expression is upregulated upon fasting (Boss et al., 1998b; Millet et al., 1997). Fasting is characterized by an increase in plasma levels of free fatty acids (FFAs), and Weigle et al. (1998) examined whether increasing plasma FFA levels could mimic the fastinginduced upregulation of UCP3. Indeed, they found that increasing plasma FFA levels upregulated UCP3 mRNA expression (Weigle et al., 1998), and this has been confirmed in humans (Khalfallah et al., 2000). Free fatty acids are ligands for peroxisome-proliferator-activated receptors, and the latter have been shown to upregulate a number of lipid-related genes as well as UCPs (Emilsson et al., 2000; Schoonjans et al., 1996). However, conditions in which plasma FFA levels are elevated are often also accompanied by increased oxidation of fatty acids, and it has therefore been suggested that UCP3 is involved in the handling of lipids as a fuel (Samec et al., 1999b), consistent with the finding that the presence of the UCP3 gene is strongly associated with fat oxidation (Argyropoulos et al., 1998).

A role for UCP3 in fatty acid metabolism would also be consistent with the observed upregulation of UCP3 after thyroid hormone treatment (Barbe et al., 2001; Gong et al., 1997), high-fat feeding (Gong et al., 1999; Schrauwen et al., 2001b) and cold exposure (Lin et al., 1998) since, in these situations, both thermogenesis and fat oxidation are stimulated. The fasting-induced upregulation of UCP3 and subsequent downregulation of UCP3 (below baseline levels)

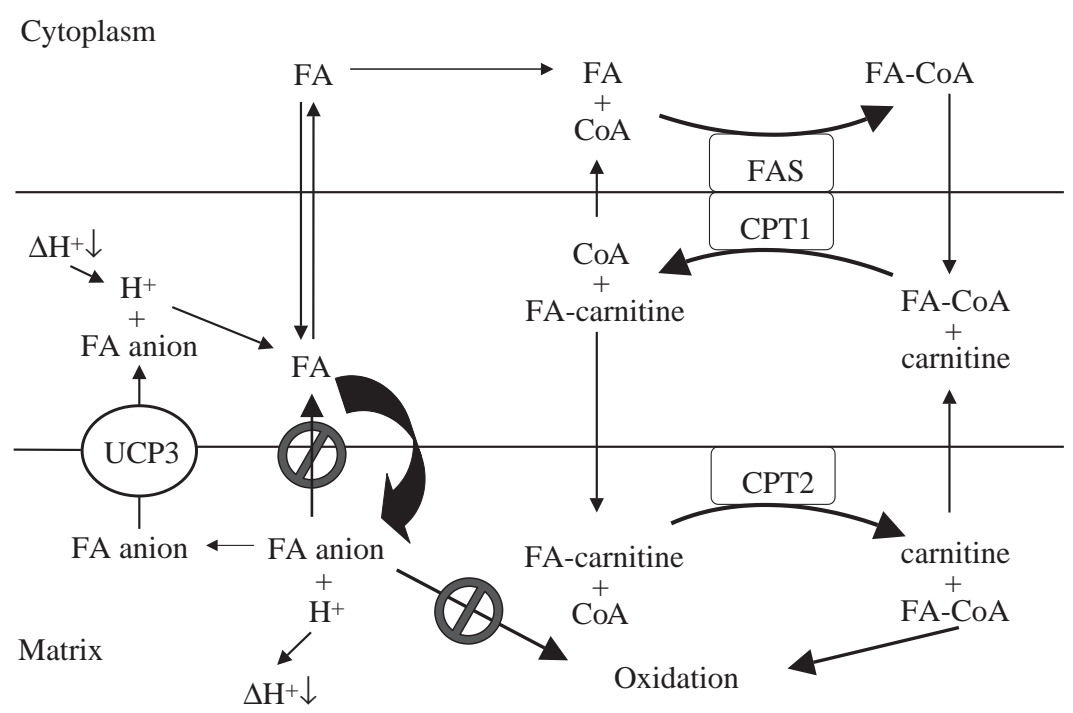

Fig. 2. Hypothesis for the function of uncoupling protein-3 (UCP3): fatty acid anions are transported out of the mitochondrial matrix to prevent accumulation of fatty acid anions inside the matrix (Schrauwen et al., 2001c). FA, fatty acid; CoA, coenzyme A; FAS, fatty acyl-CoA synthetase; CPT1, carnitine palmitoyl transferase-1; CPT2, carnitine palmitoyl transferase-2; $\Delta \mathrm{H}^{+}$, proton gradient. 
during refeeding provide further evidence that UCP3 is, in fact, more involved in fatty acid metabolism than in energy metabolism (Samec et al., 1999a). Also, the upregulation of UCP3 mRNA expression after acute exercise (Pilegaard et al., 2000) could be attributed to increased metabolic rate and increased fat oxidation in the post-exercise period. To separate these effects, we examined the combined effect of acute exercise and glucose administration, thereby preventing the usual rise in plasma FFA levels and rate of fat oxidation, on UCP3 mRNA expression. We found that UCP3 mRNA is upregulated after exercise only in the fasted state and that this increase could be completely abolished by administration of glucose (Schrauwen et al., 2002a), indicating that UCP3 is indeed more closely involved in fatty acid metabolism than in energy metabolism.

However, conditions in which UCP3 is downregulated are not characterized by low plasma FFA levels and/or low rates of fatty acid oxidation. For example, UCP3 has repeatedly been shown to be downregulated after endurance training (Boss et al., 1998a; Schrauwen et al., 1999a, 2001c), a condition in which fat oxidative capacity is enhanced (Holloszy and Coyle, 1984). In addition, weight reduction leads to an increase in capacity to oxidise fat and a decrease in UCP3 mRNA expression and in UCP3 protein content (Schrauwen et al., 2000; Vidal-Puig et al., 1999). Finally, type 1 muscle fibres, characterized by a high capacity to oxidise fat, have the lowest expression of UCP3. These findings indicate that UCP3 is downregulated in conditions of enhanced capacity to oxidise fat and upregulated in conditions in which fatty acid delivery exceeds the capacity to oxidise fat, eventually leading to an increase in plasma FFA levels (fasting, acute exercise).

As mentioned in the Introduction, UCPs could act as fatty acid anion transporters, transporting fatty acid anions out of the mitochondrial matrix (Jezek et al., 1998). We recently postulated that UCP3 might act as a fatty acid anion transporter in situations in which delivery of fatty acids to the mitochondria exceeds their capacity to oxidise fat (Schrauwen et al., 2001c). In these conditions, neutral fatty acids might accumulate in the cytoplasm, 'flip-flop' into the mitochondrial matrix and equilibrate with the $\mathrm{pH}$ gradient, thereby delivering both neutral and fatty acid anions to the matrix. Since fatty acid anions cannot flip-flop back, and since neither fatty acid anions nor neutral fatty acids can be metabolized inside the mitochondrial matrix (because no fatty acyl-CoA synthetase is present), the export of fatty acid anions out of the matrix by UCP3 might prevent the accumulation of fatty acids inside the matrix (Fig. 2). At the same time, an alternative hypothesis was postulated by Himms-Hagen and Harper (2001). In short, they also believe that UCP3 exports fatty acid anions from the mitochondrial matrix; however, according to their hypothesis, fatty acid anions are delivered by hydrolysis of acyl-CoA by mitochondrial thioesterases, thereby producing a fatty acid anion inside the matrix. Support for their hypothesis is provided by the observation that mice overexpressing UCP3 also show increased expression of mitochondrial thioesterases (Moore et al., 2001). However, the physiological importance of mitochondrial thioesterases is not fully established, and both hypotheses should be examined further.

\section{Concluding remarks}

Five years after the discovery of the UCP1 homologues UCP2 and UCP3, it has become evident that these novel uncoupling proteins are unlikely to play an important role in the regulation of adaptive thermogenesis. At least in rodents, UCP1 seems to be solely responsible for the increase in energy expenditure after cold exposure and sympathetic stimulation. However, UCP2 and UCP3 are able to uncouple respiration from ATP production and, even though their primary function is not the regulation of energy metabolism, they might still influence energy expenditure as a secondary effect of their physiological function. Therefore, UCP2 and UCP3 are still interesting targets for the treatment and prevention of obesity and diabetes. However, we must first determine the exact physiological function of these uncoupling proteins. Several putative functions have been postulated, amongst which are the prevention of ROS production, the regulation of the [ATP]:[ADP] ratio and the regulation of glucose and fatty acid metabolism and fatty acid anion export. Further studies are needed that examine the pattern of regulation of these novel uncoupling proteins under a wide variety of physiological conditions. Finally, tissue-specific upregulation of these UCPs within the physiological range might help to reveal their functional role.

P.S. was supported by a grant from the Netherlands Organization for Scientific Research (NWO).

\section{References}

Argyropoulos, G., Brown, A. M., Willi, S. M., Zhu, J., He, Y., Reitman, M., Geveo, S. M., Spruill, I. and Garvey, W. T. (1998). Effects of mutations in the human uncoupling protein 3 gene on the respiratory quotient and fat oxidation in severe obesity and type 2 diabetes. J. Clin. Invest. 102, 1345-1351.

Arsenijevic, D., Onuma, H., Pecqueur, C., Raimbault, S., Manning, B. S., Miroux, B., Couplan, E., Alves-Guerra, M. C., Goubern, M., Surwit, R., Bouillaud, F., Richard, D., Collins, S. and Ricquier, D. (2000). Disruption of the uncoupling protein-2 gene in mice reveals a role in immunity and reactive oxygen species production. Nature Genet. 26, 435-439.

Astrup, A., Bulow, J., Madsen, J. and Christensen, N. J. (1985). Contribution of BAT and skeletal muscle to thermogenesis induced by ephedrine in man. Am. J. Physiol. 248, E507-E515.

Astrup, A., Toubro, S., Dalgaard, L. T., Urhammer, S. A., Sørensen, T. I. A. and Pedersen, O. (1999). Impact of the v/v 55 polymorphism of the uncoupling protein 2 gene on 24-h energy expenditure and substrate oxidation. Int. J. Obes. Relat. Metab. Disord. 23, 1030-1034.

Bao, S., Kennedy, A., Wojciechowski, B., Wallace, P., Ganaway, E. and Garvey, W. T. (1998). Expression of mRNAs encoding uncoupling proteins in human skeletal muscle: effects of obesity and diabetes. Diabetes 47, 1935-1940.

Barbe, P., Larrouy, D., Boulanger, C., Chevillotte, E., Viguerie, N., Thalamas, C., Trastoy, M. O., Roques, M., Vidal, H. and Langin, D. (2001). Triiodothyronine-mediated up-regulation of UCP2 and UCP3 mRNA expression in human skeletal muscle without coordinated induction of mitochondrial respiratory chain genes. FASEB J. 15, 13-15.

Barbe, P., Millet, L., Larrouy, D., Galitzky, J., Berlan, M., Louvet, J.-P. and Langin, D. (1998). Uncoupling protein-2 messenger ribonucleic acid 
expression during very-low-calorie diet in obese premenopausal women. $J$. Clin. Endocrinol. Metab. 83, 2450-2453.

Boss, O., Samec, S., Desplanches, D., Mayet, M.-H., Seydoux, J., Muzzin, P. and Giacobino, J.-P. (1998a). Effect of endurance training on mRNA expression of uncoupling proteins 1,2 and 3 in the rat. FASEB J. 12, 335-339.

Boss, O., Samec, S., Kühne, F., Bijlenga, P., Assimacopoulos-Jeannet, F., Seydoux, J., Giacobino, J.-P. and Muzzin, P. (1998b). Uncoupling protein-3 expression in rodent skeletal muscle is modulated by food intake but not by changes in environmental temperature. J. Biol. Chem. 273, 5-8.

Boss, O., Samec, S., Paoloni-Giacobino, A., Rossier, C., Dulloo, A., Seydoux, J., Muzzin, P. and Giacobino, J.-P. (1997). Uncoupling protein3: a new member of the mitochondrial carrier family with tissue-specific expression. FEBS Lett. 408, 39-42.

Bouchard, C., Pérusse, L., Chagnon, Y. C., Warden, G. and Ricquier, D. (1997). Linkage between markers in the vicinity of the uncoupling protein 2 gene and resting metabolic rate in humans. Hum. Mol. Genet. 6 , 1887-1889.

Buemann, B., Schierning, B., Toubro, S., Bibby, B., Sorensen, T., Dalgaard, L., Pedersen, O. and Astrup, A. (2001). The association between the val/ala-55 polymorphism of the uncoupling protein 2 gene and exercise efficiency. Int. J. Obes. Relat. Metab. Disord. 25, 467-471.

Cassell, P. G., Neverova, M., Janmohamed, S., Uwakwe, N., Qureshi, A., McCarthy, M. I., Saker, P. J., Albon, L., Kopelman, P., Noonan, K., Easlick, J., Ramachandran, A., Snehalatha, C., Pecqueur, C., Ricquier, D., Warden, C. and Hitman, G. A. (1999). An uncoupling protein 2 gene variant is associated with a raised body mass index but not type II diabetes. Diabetologia 42, 688-692.

Cassell, P. G., Saker, P. J., Huxtable, S. J., Kousta, E., Jackson, A. E., Hattersley, A. T., Frayling, T. M., Walker, M., Kopelman, P. G., Ramachandran, A., Snehelatha, C., Hitman, G. A. and McCarthy, M. I. (2000). Evidence that single nucleotide polymorphism in the uncoupling protein 3 (UCP3) gene influences fat distribution in women of European and Asian origin. Diabetologia 43, 1558-1564.

Chan, C. B., De Leo, D., Joseph, J. W., McQuaid, T. S., Ha, X. F., Xu, F., Tsushima, R. G., Pennefather, P. S., Salapatek, A. M. and Wheeler, M. B. (2001). Increased uncoupling protein-2 levels in beta-cells are associated with impaired glucose-stimulated insulin secretion: mechanism of action. Diabetes 50, 1302-1310.

Chung, W. K., Luke, A., Cooper, R. S., Rotini, C., Vidal-Puig, A., Rosenbaum, M., Chua, M., Solanes, G., Zheng, M., Zhao, L., LeDuc, C., Eisberg, A., Chu, F., Murphy, E., Schreier, M., Aronne, L., Caprio, S., Kahle, B., Gordon, D., Leal, S. M., Goldsmith, R., Andreu, A. L., Bruno, C., DiMauro, S., Leibel, R. L. (1999). Genetic and physiologic analysis of the role of uncoupling protein 3 in human energy homeostasis. Diabetes 48, 1890-1895.

Clapham, J. C., Arch, J. R., Chapman, H., Haynes, A., Lister, C., Moore, G. B., Piercy, V., Carter, S. A., Lehner, I., Smith, S. A., Beeley, L. J., Godden, R. J., Herrity, N., Skehel, M., Changani, K. K., Hockings, P. D., Reid, D. G., Squires, S. M., Hatcher, J., Trail, B., Latcham, J., Rastan, S., Harper, A. J., Cadenas, S., Buckingham, J. A., Brand, M. D. and Abuin, A. (2000). Mice overexpressing human uncoupling protein3 in skeletal muscle are hyperphagic and lean. Nature 406, 415-418.

Comuzzie, A. G., Almasy, L., Cole, S. A., Boss, O., Giacobino, J. P., Muzzin, P., Stern, M. P., MacCluer, J. W., Blangero, J. and Hixson, J. E. (2000). Linkage exclusion analysis of the chromosome 11 region containing UCP2 and UCP3 with obesity-related phenotypes in Mexican Americans. Int. J. Obes. Relat. Metab. Disord. 24, 1065-1068.

Dalgaard, L. T., Sorensen, T. I., Andersen, T., Hansen, T. and Pedersen, O. (1999). An untranslated insertion variant in the uncoupling protein 2 gene is not related to body mass index and changes in body weight during a 26year follow-up in Danish Caucasian men. Diabetologia 42, 1413-1416.

Dalgaard, L. T., Sorensen, T. I., Drivsholm, T., Borch-Johnsen, K., Andersen, T., Hansen, T. and Pedersen, O. (2001). A prevalent polymorphism in the promoter of the UCP3 gene and its relationship to body mass index and long term body weight change in the Danish population. $J$. Clin. Endocrinol. Metab. 86, 1398-1402.

Day, C. (1999). Thiazolidinediones: a new class of antidiabetic drugs. Diabet. Med. 16, 179-192.

Desautels, M., Zaror-Behrens, G. and Himms-Hagen, J. (1978). Increased purine nucleotide binding, altered polypeptide composition and thermogenesis in brown adipose tissue mitochondria of cold-acclimated rats. Can. J. Biochem. 56, 378-383.

Elbein, S. C., Leppert, M. and Hasstedt, S. (1997). Uncoupling protein 2 region on chromosome 11q13 is not linked to markers of obesity in familial type 2 diabetes. Diabetes 46, 2105-2107.

Emilsson, V., O'Dowd, J., Wang, S., Liu, Y. L., Sennitt, M., Heyman, R. and Cawthorne, M. A. (2000). The effects of rexinoids and rosiglitazone on body weight and uncoupling protein isoform expression in the Zucker fa/fa rat. Metabolism 49, 1610-1615.

Enerback, S., Jacobsson, A., Simpson, E. M., Guerra, C., Yamashita, H., Harper, M.-E. and Kozak, L. P. (1997). Mice lacking mitochondrial uncoupling protein are cold-sensitive but not obese. Nature Genet. 387, 90-94.

Esterbauer, H., Schneitler, C., Oberkofler, H., Ebenbichler, C., Paulweber, B., Sandhofer, F., Ladurner, G., Hell, E., Strosberg, A. D., Patsch, J. R., Krempler, F. and Patsch, W. (2001). A common polymorphism in the promoter of UCP2 is associated with decreased risk of obesity in middle-aged humans. Nature Genet. 28, 178-183.

Evans, D., Wolf, A. M., Nellessen, U., Ahle, S., Kortner, B., Kuhlmann, H. W. and Beisiegel, U. (2001). Association between polymorphisms in candidate genes and morbid obesity. Int. J. Obes. Relat. Metab. Disord. 25 (Suppl. 1), S19-S21.

Fleury, C., Neverova, M., Collins, S., Raimbault, S., Champigny, O., LeviMeyrueis, C., Bouillaud, F., Seldin, M. F., Surwit, R. S., Ricquier, D. and Warden, C. H. (1997). Uncoupling protein-2: a novel gene linked to obesity and hyperinsulinemia. Nature Genet. 15, 269-273.

Gimeno, R. E., Dembski, M., Weng, X., Deng, N., Shyjan, A. W., Gimeno, C. J., Iris, F., Ellis, S. J., Woolf, E. A. and Tartaglia, L. A. (1997). Cloning and characterization of an uncoupling protein homolog: a potential molecular mediator of human thermogenesis. Diabetes 46, 900-906.

Golozoubova, V., Hohtola, E., Matthias, A., Jacobsson, A., Cannon, B. and Nedergaard, J. (2001). Only UCP1 can mediate adaptive nonshivering thermogenesis in the cold. FASEB J. 15, 2048-2050.

Gong, D.-W., He, Y., Karas, M. and Reitman, M. (1997). Uncoupling protein-3 is a mediator of thermogenesis regulated by thyroid hormone, $\beta 3$ adrenergic agonists and leptin. J. Biol. Chem. 272, $24129-24132$.

Gong, D.-W., He, Y. and Reitman, M. L. (1999). Genomic organization and regulation by dietary fat of the uncoupling protein 3 and 2 genes. Biochem. Biophys. Res. Commun. 256, 27-32.

Gong, D. W., Monemdjou, S., Gavrilova, O., Leon, L. R., MarcusSamuels, B., Chou, C. J., Everett, C., Kozak, L. P., Li, C., Deng, C., Harper, M. E. and Reitman, M. L. (2000). Lack of obesity and normal response to fasting and thyroid hormone in mice lacking uncoupling protein3. J. Biol. Chem. 275, 16251-16257.

Halsall, D., Luan, J., Saker, P., Huxtable, S., Farooqi, I., Keogh, J., Wareham, N. and O'Rahilly, S. (2001). Uncoupling protein 3 genetic variants in human obesity: the c-55t promoter polymorphism is negatively correlated with body mass index in a UK Caucasian population. Int. J. Obes. Relat. Metab. Disord. 25, 472-477.

Hesselink, M. K. C., Keizer, H. A., Borghouts, L. B., Schaart, G., Kornips, C. F. P., Slieker, L. J., Sloop, K. W., Saris, W. H. M. and Schrauwen, P. (2001). Protein expression of UCP3 differs between human type 1, type $2 \mathrm{a}$ and type $2 \mathrm{~b}$ fibers. FASEB J. 15, 1071-1073.

Himms-Hagen, J. (1984). Thermogenesis in brown adipose tissue as an energy buffer. Implications for obesity. N. Engl. J. Med. 311, 1549-1558.

Himms-Hagen, J. and Harper, M. E. (2001). Physiological role of UCP3 may be export of fatty acids from mitochondria when fatty acid oxidation predominates: an hypothesis. Exp. Biol. Med. 226, 78-84.

Holloszy, J. and Coyle, E. F. (1984). Adaptations of skeletal muscle to endurance exercise and their metabolic consequences. J. Appl. Physiol. 56, 831-838.

Huppertz, C., Fischer, B. M., Kim, Y. B., Kotani, K., Vidal-Puig, A., Slieker, L. J., Sloop, K. W., Lowell, B. B. and Kahn, B. B. (2001). Uncoupling protein 3 (UCP3) stimulates glucose uptake in muscle cells through a phosphoinositide 3-kinase-dependent mechanism. J. Biol. Chem. 276, 12520-12529.

Jezek, P., Engstová, H., Zácková, M., Vercesi, A. E., Costa, A. D. T., Arruda, P. and Garlid, K. D. (1998). Fatty acid cycling mechanism and mitochondrial uncoupling proteins. Biochim. Biophys. Acta 1365, 319-327.

Khalfallah, Y., Fages, S., Laville, M., Langin, D. and Vidal, H. (2000). Regulation of uncoupling protein-2 and uncoupling protein-3 mRNA expression during lipid infusion in human skeletal muscle and subcutaneous adipose tissue. Diabetes 49, 25-31.

Klannemark, M., Orho, M. and Groop, L. (1998). No relationship between identified variants in the uncoupling protein 2 gene and energy expenditure. Eur. J. Endocrinol. 139, 217-223.

Klingenberg, M., Echtay, K. S., Bienengraeber, M., Winkler, E. and 
Huang, S. G. (1999). Structure-function relationship in UCP1. Int. J. Obes. Relat. Metab. Disord. 23 (Suppl. 6), S24-S29.

Krook, A., Digby, J., O'Rahilly, S., Zierath, J. R. and WallbergHenriksson, H. (1998). Uncoupling protein 3 is reduced in skeletal muscle of NIDDM patients. Diabetes 47, 1528-1531.

Kubota, T., Mori, H., Tamori, Y., Okazawa, H., Fukuda, T., Miki, M., Ito, C., Fleury, C., Bouillaud, F. and Kasuga, M. (1998). Molecular screening of uncoupling protein 2 gene in patients with noninsulin-dependent diabetes mellitus or obesity. J. Clin. Endocrinol. Metab. 83, 2800-2804.

Lean, M. E., James, W. P., Jennings, G. and Trayhurn, P. (1986). Brown adipose tissue uncoupling protein content in human infants, children and adults. Clin. Sci. 71, 291-297.

Lentes, K.-U., Tu, N., Chen, H., Winnikes, U., Reinert, I., Marmann, G. and Pirke, K. M. (1999). Genomic organization and mutational analysis of the human UCP2 gene, a prime candidate gene for human obesity. J. Recept. Signal Transduct. Res. 19, 229-244.

Li, B., Nolte, L. A., Ju, J. S., Ho Han, D., Coleman, T., Holloszy, J. O. and Semenkovich, C. F. (2000). Skeletal muscle respiratory uncoupling prevents diet-induced obesity and insulin resistance in mice. Nature Med. 6, $1115-1120$.

Lin, B., Coughlin, S. and Pilch, P. F. (1998). Bidirectional regulation of uncoupling protein-3 and GLUT-4 mRNA in skeletal muscle by cold. Am. J. Physiol. 275, E386-E391.

Meirhaeghe, A., Amouyel, P., Helbecque, N., Cottel, D., Otabe, S., Froguel, P. and Vasseur, F. (2000). An uncoupling protein 3 gene polymorphism associated with a lower risk of developing Type II diabetes and with atherogenic lipid profile in a French cohort. Diabetologia 43, $1424-1428$

Millet, L., Vidal, H., Andreelli, F., Larrouy, D., Riou, J.-P., Ricquier, D., Laville, M. and Langin, D. (1997). Increased uncoupling protein-2 and -3 mRNA expression during fasting in obese and lean humans. J. Clin. Invest. 100, 2665-2670.

Mitchell, P. (1966). Chemiosmotic coupling in oxidative and photosynthetic phosphorylation. Biol. Rev. 41, 445-502.

Moore, G. B., Himms-Hagen, J., Harper, M. E. and Clapham, J. C. (2001). Overexpression of UCP-3 in skeletal muscle of mice results in increased expression of mitochondrial thioesterase mRNA. Biochem. Biophys. Res. Commun. 283, 785-790.

Nedergaard, J., Golozoubova, V., Matthias, A., Asadi, A., Jacobsson, A. and Cannon, B. (2001). UCP1: the only protein able to mediate adaptive non-shivering thermogenesis and metabolic inefficiency. Biochim. Biophys. Acta 1504, 82-106.

Nègre-Salvayre, A., Hirtz, C., Carrera, G., Cazenave, R., Troly, M., Salvayre, R., Pénicaud, L. and Casteilla, L. (1997). A role for uncoupling protein-2 as a regulator of mitochondrial hydrogen peroxide generation. FASEB J. 11, 809-815

Nicholls, D., Bernson, V. and Heaton, G. (1978). The identification of the component in the inner membrane responsible for regulating energy dissipation. In Effectors of Thermogenesis (ed. L. Girardier and J. Seydoux), pp. 89-93. Basel: Birkhauser Verlag.

Nishikawa, T., Edelstein, D., Du, X. L., Yamagishi, S., Matsumura, T., Kaneda, Y., Yorek, M. A., Beebe, D., Oates, P. J., Hammes, H. P., Giardino, I. and Brownlee, M. (2000). Normalizing mitochondrial superoxide production blocks three pathways of hyperglycaemic damage. Nature 404, 787-790

Nordfors, L., Hoffstedt, J., Nyberg, B., Thörne, A., Arner, P., Schalling, M. and Lönnqvist, F. (1998). Reduced gene expression of UCP2 but not UCP3 in skeletal muscle of human obese subjects. Diabetologia $\mathbf{4 1}$, 935-939.

Oberkofler, H., Liu, Y. M., Esterbauer, H., Hell, E., Krempler, F. and Patsch, W. (1998). Uncoupling protein-2 gene: reduced mRNA expression in intraperitoneal adipose tissue of obese humans. Diabetologia 41, 940-946.

Oberkofler, H., Neschen, S., Esterbauer, H., Waldhausl, W., Patsch, W. and Furnsinn, C. (2000). UCP3 gene expression does not correlate with muscle oxidation rates in troglitazone-treated Zucker fatty rats. Biochim. Biophys. Acta 1517, 113-118.

Otabe, S., Clement, K., Dina, C., Pelloux, V., Guy-Grand, B., Froguel, P. and Vasseur, F. (2000). A genetic variation in the $5^{\prime}$ flanking region of the UCP3 gene is associated with body mass index in humans in interaction with physical activity. Diabetologia $\mathbf{4 3}, 245-249$.

Otabe, S., Clement, K., Rich, N., Warden, C., Pecqueur, C., Neverova, M., Raimbault, S., Guy-Grand, B., Basdevant, A., Ricquier, D., Froquel, P. and Vasseur, F. (1998). Mutation screening of the human UCP2 gene in normoglycemic and NIDDM morbidly obese patients: Lack of association between new UCP2 polymorphisms and obesity in French Caucasians. Diabetes 47, 840-842.

Pilegaard, H., Ordway, G. A., Saltin, B. and Neufer, P. D. (2000). Transcriptional regulation of gene expression in human skeletal muscle during recovery from exercise. Am. J. Physiol. 279, E806-E814.

Ravussin, E., Lillioja, S., Knowler, W. C., Christen, L., Freymond, D., Abbott, W. G. H., Boyce, V., Howard, B. V. and Bogardus, C. (1988) Reduced rate of energy expenditure as a risk factor for body-weight gain. N. Engl. J. Med. 318, 467-472.

Rothwell, N. J., Saville, M. E. and Stock, M. J. (1984). Brown fat activity in fasted and refed rats. Biosci. Rep. 4, 351-357.

Samec, S., Seydoux, J. and Dulloo, A. G. (1999a). Post-starvation gene expression of skeletal muscle uncoupling protein 2 and uncoupling protein 3 in response to dietary fat levels and fatty acid composition. A link with insulin resistance. Diabetes 48, 436-441.

Samec, S., Seydoux, J. and Dulloo, A. G. (1999b). Skeletal muscle UCP3 and UCP2 gene expression in response to inhibition of free fatty acid flux through mitochondrial beta-oxidation. Pfiugers Arch. 438, 452-457.

Schoonjans, K., Staels, B. and Auwerx, J. (1996). Role of the peroxisome proliferator-activated receptor (PPAR) in mediating the effects of fibrates and fatty acids on gene expression. J. Lipid Res. 37, 907-925.

Schrauwen, P., Hesselink, M. K. C., Blaak, E. E., Borghouts, L. B., Schaart, G., Saris, W. H. M. and Keizer, H. A. (2001a). Uncoupling protein 3 content is decreased in skeletal muscle of patients with type 2 diabetes. Diabetes 50, 2870-2873.

Schrauwen, P., Hesselink, M. K. C., Vaartjes, I., Kornips, E., Saris, W. H. M., Giacobino, J.-P. and Russell, A. (2002a). The effect of acute exercise on uncoupling protein 3 is a fat metabolism mediated effect. Am. J. Physiol. 282, E11-E17.

Schrauwen, P., Hoppeler, H., Billeter, R., Bakker, A. and Pendergast, D. (2001b). Fiber type dependent upregulation of human skeletal muscle UCP2 and UCP3 mRNA expression by high-fat diet. Int. J. Obes. Relat. Metab. Disord. 25, 449-456.

Schrauwen, P., Saris, W. H. and Hesselink, M. K. (2001c). An alternative function for human uncoupling protein 3: protection of mitochondria against accumulation of nonesterified fatty acids inside the mitochondrial matrix. FASEB J. 15, 2497-2502.

Schrauwen, P., Schaart, G., Saris, W. H. M., Slieker, L. J., Glatz, J. F. C., Vidal, H. and Blaak, E. E. (2000). The effect of weight reduction on skeletal muscle UCP2 and UCP3 mRNA expression and UCP3 protein content in type II diabetic subjects. Diabetologia 43, 1408-1416.

Schrauwen, P., Troost, F. J., Xia, J., Ravussin, E. and Saris, W. H. M. (1999a). Skeletal muscle UCP2 and UCP3 expression in trained and untrained male subjects. Int. J. Obes. Relat. Metab. Disord. 23, 966-972.

Schrauwen, P., Westerterp-Plantenga, M. S., Kornips, E., Schaart, G. and Marken Lichtenbelt, W. D. (2002b). The effect of mild cold exposure on UCP3 mRNA expression and UCP3 protein content in humans. Int. J. Obes. Relat. Metab. Disord. 26, 450-457.

Schrauwen, P., Xia, J., Bogardus, C., Pratley, R. and Ravussin, E. (1999b). Skeletal muscle UCP3 expression is a determinant of energy expenditure in Pima Indians. Diabetes 48, 146-149.

Schrauwen, P., Xia, J., Walder, K., Snitker, S. and Ravussin, E. (1999c). A novel polymorphism in the proximal UCP3 promoter region: effect on skeletal muscle UCP3 mRNA expression and obesity in male non-diabetic Pima Indians. Int. J. Obes. Relat. Metab. Disord. 23, 1242-1245.

Shiinoki, T., Suehiro, T., Ikeda, Y., Inoue, M., Nakamura, T., Kumon, Y., Nakauchi, Y. and Hashimoto, K. (1999). Screening for variants of the uncoupling protein 2 gene in Japanese patients with non-insulin-dependent diabetes mellitus. Metabolism 48, 581-584.

Simonsen, L., Stallknecht, B. and Bulow, J. (1993). Contribution of skeletal muscle and adipose tissue to adrenaline-induced thermogenesis in man. Int. J. Obes. Relat. Metab. Disord. 17 (Suppl. 3), S47-S51.

Skulachev, V. P. (1998). Uncoupling: new approaches to an old problem of bioenergetics. Biochim. Biophys. Acta 1363, 100-124.

Solanes, G., Vidal-Puig, A., Grujic, D., Flier, J. S. and Lowell, B. B. (1997). The human uncoupling protein-3 gene: genomic structure, chromosomal localization and genetic basis for short and long form transcripts. J. Biol. Chem. 272, 25433-25436.

Trayhurn, P. and Jennings, G. (1988). Nonshivering thermogenesis and the thermogenic capacity of brown fat in fasted and/or refed mice. Am. $J$. Physiol. 254, R11-R16.

Tremblay, A., Plourde, G., Despres, J. P. and Bouchard, C. (1989). Impact 
of dietary fat content and fat oxidation on energy intake in humans. Am. J. Clin. Nutr. 49, 799-805.

Tsuboyama-Kasaoka, N., Tsunoda, N., Maruyama, K., Takahashi, M., Kim, H., Ikemoto, S. and Ezaki, O. (1998). Up-regulation of uncoupling protein 3 (UCP3) mRNA by exercise training and down-regulation of UCP3 by denervation in skeletal muscles. Biochem. Biophys. Res. Commun. 247, 498-503.

Urhammer, S. A., Dalgaard, L. T., Sørensen, T. I. A., Møller, A. M., Andersen, T., Tybjœrg-Hansen, A., Hansen, T., Clausen, J. O., Vestergaard, H. and Pedersen, O. (1997). Mutational analysis of the coding region of the uncoupling protein 2 gene in obese NIDDM patients: Impact of a common amino acid polymorphism on juvenile and maturity onset forms of obesity and insulin resistance. Diabetologia 40, $1227-1230$.

Urhammer, S. A., Dalgaard, L. T., Sørensen, T. I. A., Tybjœrg-Hansen, A., Echwald, S. M., Andersen, T., Clausen, J. O. and Pedersen, O. (1998). Organisation of the coding exons and mutational screening of the uncoupling protein 3 gene in subjects with juvenile-onset obesity. Diabetologia 41, 241-244.

Vidal, H., Langin, D., Andreelli, F., Millet, L., Larrouy, D. and Laville, M. (1999). Lack of skeletal muscle uncoupling protein 2 and 3 mRNA induction during fasting in type-2 diabetic subjects. Am. J. Physiol. 277, E830-E837.

Vidal-Puig, A. J., Grujic, D., Zhang, C. Y., Hagen, T., Boss, O., Ido, Y., Szczepanik, A., Wade, J., Mootha, V., Cortright, R., Muoio, D. M. and Lowell, B. B. (2000). Energy metabolism in uncoupling protein 3 gene knockout mice. J. Biol. Chem. 275, 16258-16266.
Vidal-Puig, A., Rosenbaum, M., Considine, R. C., Leibel, R. L., Dohm, G. L. and Lowell, B. B. (1999). Effects of obesity and stable weight reduction on UCP2 and UCP3 gene expression in humans. Obes. Res. 7, 133-140.

Walder, K., Norman, R. A., Hanson, R. L., Schrauwen, P., Neverova, M., Jenkinson, C. P., Easlick, J., Warden, C. H., Pecqueur, C., Raimbault, S., Riquier, D., Silver, M. H. K., Shuldiner, A. R., Solanes, G., Lowell, B. B., Chung, W. K., Leibel, R. L., Pratley, R. and Ravussin, E. (1998). Association between uncoupling protein polymorphisms (UCP2-UCP3) and energy metabolism/obesity in Pima Indians. Hum. Mol. Genet. 7, 1431-1435.

Weigle, D. S., Selfridge, L. E., Schwartz, M. W., Seeley, R. J., Cummings, D. E., Havel, P. J., Kuijper, J. L. and BertrandelRio, H. (1998). Elevated free fatty acids induce uncoupling protein 3 expression in muscle. A potential explanation for the effect of fasting. Diabetes 47, 298-302.

Winder, W. W. and Hardie, D. G. (1999). AMP-activated protein kinase, a metabolic master switch: possible roles in type 2 diabetes. Am. J. Physiol. 277, E1-E10.

Yanovski, J. A., Diament, A. L., Sovik, K. N., Nguyen, T. T., Li, H., Sebring, N. G. and Warden, C. H. (2000). Associations between uncoupling protein 2 , body composition and resting energy expenditure in lean and obese African American, white and Asian children. Am. J. Clin. Nutr. 71, 1405-1420.

Zhang, C., Baffy, G., Perret, P., Krauss, S., Peroni, O., Grujic, D., Hagen, T., Vidal-Puig, A. J., Boss, O., Kim, Y., Zheng, X. X., Wheeler, M. B., Shulman, G. I., Chan, C. B. and Lowell, B. B. (2001). Uncoupling protein2 negatively regulates insulin secretion and is a major link between obesity, beta cell dysfunction and type 2 diabetes. Cell 105, 745-755. 